\title{
A REASSESSMENT OF THE DISTRIBUTION OF VIRGINIA'S WARBLER IN THE BLACK HILLS OF SOUTH DAKOTA
}

\author{
DAVID L. SWANSON and MARK D. DIXON, Department of Biology, University \\ of South Dakota, 414 E. Clark Street, Vermillion, South Dakota 57069-2390; \\ david.swanson@usd.edu \\ JEFFREY S. PALMER, College of Arts \& Sciences, Dakota State University, Madi- \\ son, South Dakota 57042
}

ABSTRACT: Virginia's Warbler (Oreothlypis virginiae) reaches the northeastern limit of its breeding range in the southern Black Hills of South Dakota, where it is considered a species of conservation concern. This population occurs in pine-juniper-shrub habitat in several canyons in extreme western Custer County. Additional such habitat occurs in the southern Black Hills south and east of the documented breeding populations, but these areas have received few systematic surveys, and whether Virginia's Warbler occupies them was uncertain. Therefore, to define the species' distribution in the South Dakota Black Hills more precisely, we surveyed with the aid of broadcast song and reviewed other reports. Virginia's Warblers occurred in appropriate habitats all along the southwestern front (approximately $30 \mathrm{~km}$ total) of the Black Hills in Custer County but did not occur in similar habitat along the southeastern front, approximately $25 \mathrm{~km}$ distant. The species' relative abundance in previously and newly identified pine-juniper-shrub habitats was similar. Virginia's Warbler occurrence was positively associated with shrub cover (primarily mountain-mahogany, Cercocarpus montanus), pine overstory, and slopes of $>15^{\circ}$. Its association with the Spotted Towhee (Pipilo maculatus) was negative, with the Yellow-rumped Warbler (Setophaga coronata) tended toward positive, and with the Dusky Flycatcher (Empidonax oberholseri) was variable (negative along the southwestern front but weakly positive across all sites). These data extend the documented breeding range of Virginia's Warbler in South Dakota by more than $20 \mathrm{~km}$ to the southeast. To clarify conservation priorities for this species at the northeastern limit of its range, future studies should delineate local and landscape-level characteristics of this population's habitat more precisely and address its source-sink population dynamics.

Virginia's Warbler (Oreothlypis virginiae) nests widely in mountainous regions of southwestern North America from southeastern Idaho and southwestern Wyoming into southern Arizona, New Mexico, and western Texas (Olson and Martin 1999). The species' northeasternmost population is isolated in the southwestern Black Hills of South Dakota, separated by over $200 \mathrm{~km}$ from the next nearest breeding population in south-central Wyoming (Swanson et al. 2000). Breeding habitat occurs on mountain slopes and consists of dense, shrubby vegetation with taller plants interspersed or nearby (Olson and Martin 1999). In various portions of the breeding range the shrubby vegetation may include chokecherry (Prunus virginiana), snowberry (Symphoricarpos spp.), currant (Ribes spp.), serviceberry (Amelanchier spp.), manzanita (Arctostaphylos spp.), scrub oak (Quercus gambelii), or mountain-mahogany (Cercocarpus montanus) (Olson and Martin 1999). The taller vegetation may consist of pinyon pine (Pinus spp.), juniper (Juniperus spp.), ponderosa pine (Pinus ponderosa), Douglas-fir (Pseudotsuga menziesii), taller scrub oak, or aspen (Populus tremuloides) (Olson and Martin 1999).

Virginia's Warbler was first definitively recorded in South Dakota in 1997, 
when several birds were located in Redbird, Roby and Boles canyons in western Custer County (Palmer 1998). The following year, Swanson et al. (2000) found this species to occur in several canyons north of Highway 16 in the southwestern Black Hills, including Whoopup, Roby, Boles, Redbird, and Buck Spring canyons (Figure 1). Virginia's Warbler was among the more common birds in this habitat (Swanson et al. 2002). Since those original surveys, a few Virginia's Warblers have been documented during the breeding season south of Highway 16 in Custer County (White and Giroir 2009, Bird Conservancy of the Rockies 2015, pers. obs.). In all cases, the birds were on relatively steep slopes with some ponderosa pine overstory or scattered trees and a thick shrubby understory of mountain-mahogany and skunkbush sumac, Rhus aromatica (Swanson et al. 2000). This habitat type is restricted in South Dakota primarily to the southwestern Black Hills of Custer County (Hoffman and Alexander 1987); portions have been burned or threatened by recent wildfires. Because of its limited range in South Dakota, its specific habitat requirements, and the susceptibility of those limited habitats to wildfire, Virginia's Warbler is listed as category S3B (found locally in a restricted

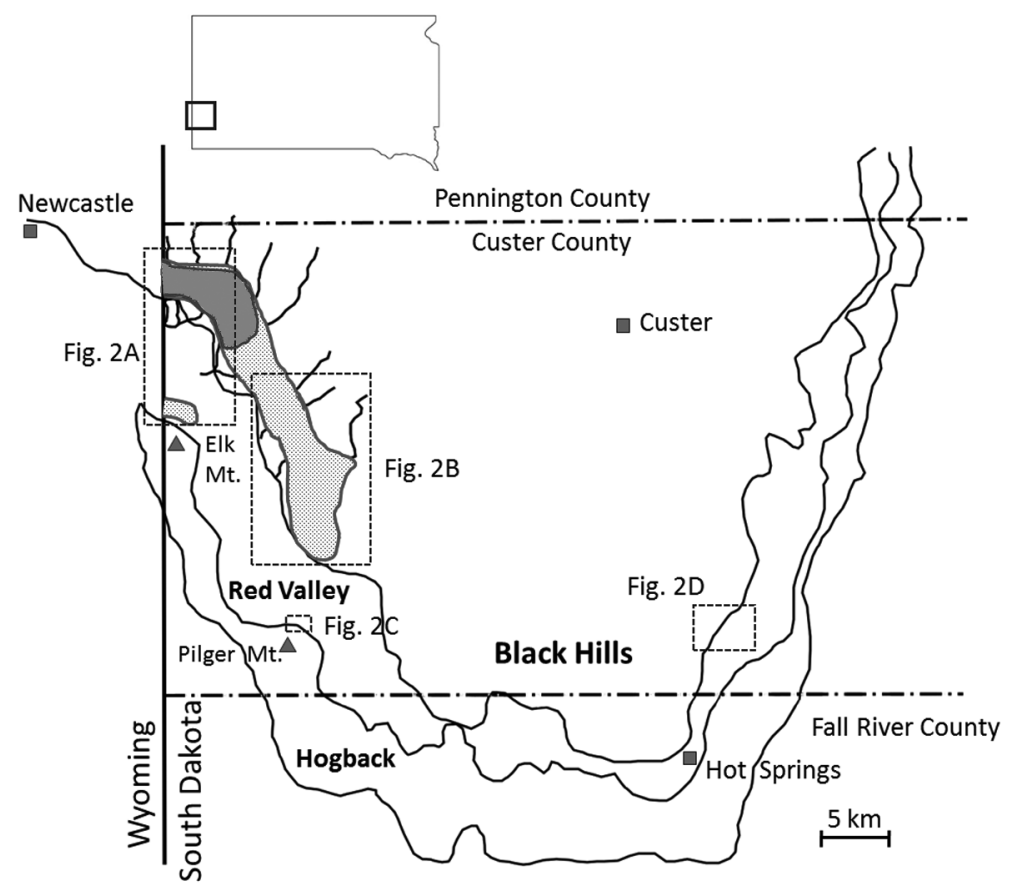

Figure 1. Range of Virginia's Warbler in the southwestern Black Hills, Custer County, South Dakota. Dark gray shading, range described by Swanson et al. (2000); stippling, range based on surveys in 2015 , in which the birds are localized in canyon bottoms with appropriate slopes and pine-juniper-shrub habitat. Dashed boxes specify survey areas mapped in Figures 2A-D. 
range) in the South Dakota Natural Heritage database (http://gfp.sd.gov/ wildlife/threatened-endangered/rare-animal.aspx).

Our observations of Virginia's Warblers south of Highway 16 in pine-juniper-shrub (PJS) habitat in Schenk and lower Hell canyons, Custer County, South Dakota, as well as by surveys by the Bird Conservancy of the Rockies (White and Giroir 2009, Bird Conservancy of the Rockies 2015), suggested that the range of the Virginia's Warbler in the South Dakota Black Hills extends farther south than documented by Swanson et al. (2000). In addition, we were recently made aware of some fairly extensive PJS habitat possibly appropriate for Virginia's Warbler approximately $25 \mathrm{~km}$ farther east in the 2011 Sanson Ranch addition to Wind Cave National Park on the eastern slope of the southern Black Hills in Beaver Creek and Wind Cave canyons (Duane Weber, Wind Cave National Park, pers. comm.).

Despite the Black Hills population being discovered 19 years ago, some recent publications reporting the geographic distribution of Virginia's Warbler have not included it within the breeding range (e.g., New Mexico Partners in Flight 2007, Stephenson and Whittle 2013; Audubon Online Guide to North American Birds, https://www.audubon.org/field-guide/ bird/virginias-warbler). Thus further data on the distribution and ecology of Virginia's Warbler in South Dakota are needed, especially data that may be important for management of this locally distributed species at the northeastern limit of its range.

\section{METHODS}

\section{Study Sites}

To determine the presence and relative abundance of Virginia's Warbler in the southern Black Hills of South Dakota, we surveyed PJS habitats both within and outside of the range documented by Swanson et al. (2000) (Figure 1). To establish a baseline for relative abundance, we surveyed within the previously documented range in Roby and Redbird canyons in Custer County. Potentially appropriate habitat also occurs south of these sites in Schenk and Hell canyons of western Custer County and in Beaver Creek and Wind Cave canyons in the Sanson Ranch addition to Wind Cave National Park. The two latter canyons lie on the southeastern front of the southern Black Hills approximately $25 \mathrm{~km}$ east of any sites of Virginia's Warbler breeding currently known in South Dakota. To locate additional suitable habitat, we identified prospective sites with Google Earth, then scouted these canyons in southern Custer County along the southwestern slopes of the Black Hills at elevations of 1350-1700 m, where PJS habitat and Virginia's Warblers occur (Swanson et al. 2000, 2002). Our surveys included Baldwin Springs, Teepee Canyon, and several other isolated sites in Custer County.

\section{Survey Techniques}

We hiked along canyon bottoms in PJS habitat, stopping approximately every $300 \mathrm{~m}$. If no such habitat was present at $300 \mathrm{~m}$ from the last survey point, we surveyed at the next patch beyond $300 \mathrm{~m}$. We terminated surveys 
when PJS habitat was replaced along the canyon bottom by ponderosa pine forest, at an elevation of approximately $1700 \mathrm{~m}$ (Swanson et al. 2000). Our surveys extended from 2 to 8 July 2015. We chose this period because in South Dakota Virginia's Warblers sing territorially from late May to mid-July (Drilling et al. 2016) and we wanted to maximize our chance of observing parental care behaviors (e.g., carrying food), which is highest from early to mid-July (Swanson et al. 2000; Tallman et al. 2002). Surveys lasted from sunrise to $1200 \mathrm{MDT}$ under conditions of no rain and light winds ( $<25 \mathrm{~km} / \mathrm{hr}$ ).

Using iPods attached to X-mini portable stereo speakers, we broadcast Virginia's Warbler song and calls from the Stokes Western Guide to Bird Song and Peterson Guide to Western Bird Songs, both of which successfully attracted birds, principally territorial males, but in many cases also females. These playback surveys lasted for $5 \mathrm{~min}$ total and consisted of an initial $1 \mathrm{~min}$ of silent listening, followed by three cycles of alternating 30-sec periods of broadcast then silent listening, followed by a final 1-min period of silent listening. We conservatively recorded the number of Virginia's Warblers detected (including both males and females) and also recorded the identity of all other bird species observed at each survey point. For every survey point, we recorded a GPS location and these coarse-scale habitat variables: slope ( 3 categories: $0=$ none, $1=$ moderate $<15^{\circ}$, and $2=$ steep $>15^{\circ}$ ), mahogany/sumac cover ( 3 categories: $0=$ none, $1=<33 \%$ of ground cover, $2=>33 \%$ of ground cover), and ponderosa pine cover (4 categories: $0=$ none, 1 = trees restricted to the base of slopes, 2 = scattered trees/partial overstory, 3 = complete overstory).

\section{Data Analysis}

We used the presence/absence data from our playback surveys, along with previous records from nonplayback surveys (Swanson et al. 2000, White and Giroir 2009, Bird Conservancy of the Rockies 2015) and a compilation of other breeding-season records from the South Dakota Ornithologists' Union database (http://sdou.org), to map the distribution of Virginia's Warbler in the southern Black Hills of South Dakota more precisely. We calculated relative abundance (birds per survey point, including both males and females if both responded to playback) from playback surveys in PJS habitat from both the known distribution (Swanson et al. 2000) and the additional sites we surveyed in 2015 . We compared mean relative abundances by canyon where we detected birds with one-way ANOVA to determine whether relative abundances at newly documented sites differed from those within the range documented by Swanson et al. (2000). We used both univariate statistical tests (chi-squared or Fisher's exact test, if the expected number of observations per group was $<5$ ) and logistic regression models with model selection $\left(\mathrm{AIC}_{c}\right)$ to examine presence/absence of Virginia's Warblers as a function of the ordinal habitat variables described above and of the occurrence of the Dusky Flycatcher (Empidonax oberholseri), Yellow-rumped Warbler (Setophaga coronata), and Spotted Towhee (Pipilo maculatus) at each site. These three species are common in PJS habitats in South Dakota, but each has slightly different habitat requirements (Swanson et al. 2002). We used SAS (version 9.4, Cary, NC) for all statistical analyses. 


\section{RESULTS}

Playback Surveys

We surveyed 107 points and detected Virginia's Warblers at 48 (Table 1, Figure 2). The occurrence of Virginia's Warblers on the northernmost slopes of Elk Mountain, in the McKenna Spring area of Hell Canyon, in the Cedar Spring area of lower Hell Canyon, at Baldwin Springs, and in Teepee Canyon were all new locations for the species during the breeding season. Thus Virginia's Warblers are widespread along the southwestern front of the Black Hills in Custer County, wherever extensive PJS habitat is present. In addition, we observed three individuals carrying food, one at Elk Mountain and two at different locations in Hell Canyon, the first confirmations of Virginia's Warbler breeding in the Black Hills south of Highway 16. Surprisingly, we did not find Virginia's Warblers in the PJS habitat in Schenk Canyon, where we have found them before on multiple occasions (pers. obs.). Neither did we find any in the Sanson Ranch addition to Wind Cave National Park ( $n=25$ survey points), despite seemingly appropriate PJS habitat in both Beaver Creek and Wind Cave canyons.

Percentage occurrence of Virginia's Warblers in the surveyed canyons varied from 0 to $100 \%$, but birds occurred at $25-100 \%$ of survey points within occupied canyons (Table 1). Virginia's Warblers occurred at $70 \%$ of all surveyed sites within the previously documented range (Swanson et al. $2000)$, a percentage similar to that (64\%) in occupied canyons in the newly

Table 1 Results of Surveys for Virginia's Warbler in the Black Hills, July 2015

\begin{tabular}{lcccc}
\hline Location & $\begin{array}{c}\text { Survey } \\
\text { points }\end{array}$ & $\begin{array}{c}\text { Bird } \\
\text { points }^{a}\end{array}$ & \% Occurrence & $\begin{array}{c}\text { Relative } \\
\text { abundance }^{b}\end{array}$ \\
\hline $\begin{array}{l}\text { Roby and lower Boles } \\
\quad \text { canyons }\end{array}$ & 18 & 11 & 62 & $0.9 \pm 0.2$ \\
$\begin{array}{l}\text { Redbird Canyon } \\
\text { Lower Hell Canyon } \\
\quad \text { (McKenna Spring area) }\end{array}$ & 5 & 5 & 100 & $1.2 \pm 0.2$ \\
$\begin{array}{l}\text { Lower Hell Canyon and } \\
\quad \text { Rattlesnake Hill" }\end{array}$ & 13 & 10 & 77 & $1.2 \pm 0.2$ \\
$\begin{array}{l}\text { Elk Mountain (northern face) } \\
\text { Schenk Canyon }\end{array}$ & 4 & 1 & 25 & - $^{d}$ \\
$\begin{array}{l}\text { Pleasant Valley } \\
\text { Lowermost Hell Canyon }\end{array}$ & 4 & 0 & 0 & 0 \\
$\quad$ (Cedar Spring area) & 13 & 0 & 0 & 0 \\
$\begin{array}{l}\text { Baldwin Springs and Teepee } \\
\quad \text { Canyon }\end{array}$ & 13 & 6 & 77 & $0.9 \pm 0.2$ \\
$\begin{array}{l}\text { Beaver Creek Canyon } \\
\text { Wind Cave Canyon }\end{array}$ & 17 & 0 & 46 & $0.5 \pm 0.2$ \\
\hline
\end{tabular}

${ }^{a}$ Number of points where Virginia's Warblers were detected.

${ }^{b}$ Mean number of birds per point, plus or minus standard error.

cSite previously reported by Swanson et al. (2000).

${ }^{d}$ Relative abundance not calculated for the Elk Mountain sites because two of these sites were on private property and the points from which we broadcast Virginia's Warbler song on public land were at least $80 \mathrm{~m}$ away from appropriate PJS habitat. Thus we suspect detectability of birds at this distance was reduced and that the numbers recorded were an underestimate. 
documented range south of Highway 16. Moreover, relative abundance (birds per point) within occupied canyons did not differ significantly by canyon $\left(F_{5,69}\right.$ $=1.095, P=0.371$ ), so relative abundance within the newly documented range was also similar to that in the previously documented range.

\section{Updated Distribution}

Combining the results of this study with previous data from nonplayback surveys (Swanson et al. 2000, White and Giroir 2009, Bird Conservancy of the Rockies 2015) and other records in the South Dakota Ornithologists' Union database (http://sdou.org) demonstrates that Virginia's Warblers occur in extensive PJS habitats along the entire southwestern front of the southern Black Hills in Custer County (Figure 1). We did not survey the more southern reaches of the Black Hills in Fall River County because we did not locate PJS habitats in those areas. Absent this habitat, Virginia's Warbler is unlikely to occur as a breeding species. These data extend the breeding range of Virginia's Warbler in South Dakota by more than $20 \mathrm{~km}$ to the southeast, along the southwestern front of the southern Black Hills. Canyons along the southeastern front of the Black Hills in Wind Cave National Park were not occupied, however, despite the PJS habitats in these canyons. Similarly, we found no Dusky Flycatchers there, despite that species nesting commonly in PJS habitats along the southwestern front of the Black Hills (Swanson et al. 2002).

\section{Correlations with Habitat and Other Birds}

Of the 107 points surveyed, $94.4 \%$ had slopes $>15^{\circ}$ and $85 \%$ had shrub cover exceeding 33\%. The most common category of pine cover at our survey points, comprising $73 \%$ of all points, was scattered pines/partial overstory. At $8 \%$ of sites pine overstory was complete, whereas at $18 \%$ pines were confined to the base of the slope abutting against the shrub habitat. Chi-squared or Fisher's exact tests of warbler occurrence in canyons along the southwestern front ( $n=82$ points) revealed a significant positive association with shrub cover $>33 \%\left(\chi^{2}=4.451, P=0.035\right)$. Pine overstory was not a significant predictor of Virginia's Warbler occurrence $\left(\chi^{2}=3.517, P=\right.$ $0.319)$ in this area, but we sampled too few sites without pine ( $n=3$, none of which had Virginia's Warblers) to assess the effect of pine absence on warbler presence properly. Likewise, we sampled too few sites with slopes shallower than $15^{\circ}$ ( $n=6$, none of which had Virginia's Warblers) to address the relationship of slope on Virginia's Warbler occurrence, although steeper slopes were significantly associated with Virginia's Warbler presence across all survey points ( $n=107$, Fisher's exact test, $P=0.034$ ). For all 107 sites sampled, Virginia's Warbler was associated negatively with the Spotted Towhee $\left(\chi^{2}=4.572, P=0.033\right)$, but this relationship did not hold when only canyons along the southwestern front were included in analyses. The Dusky Flycatcher and Yellow-rumped Warbler had no significant association with Virginia's Warbler, whether the comparison was based on either southwestern front canyons only or all sites, although a positive association with the Yellow-rumped Warbler on the basis of all sites approached significance $\left(\chi^{2}=3.415, P=0.065\right)$. 

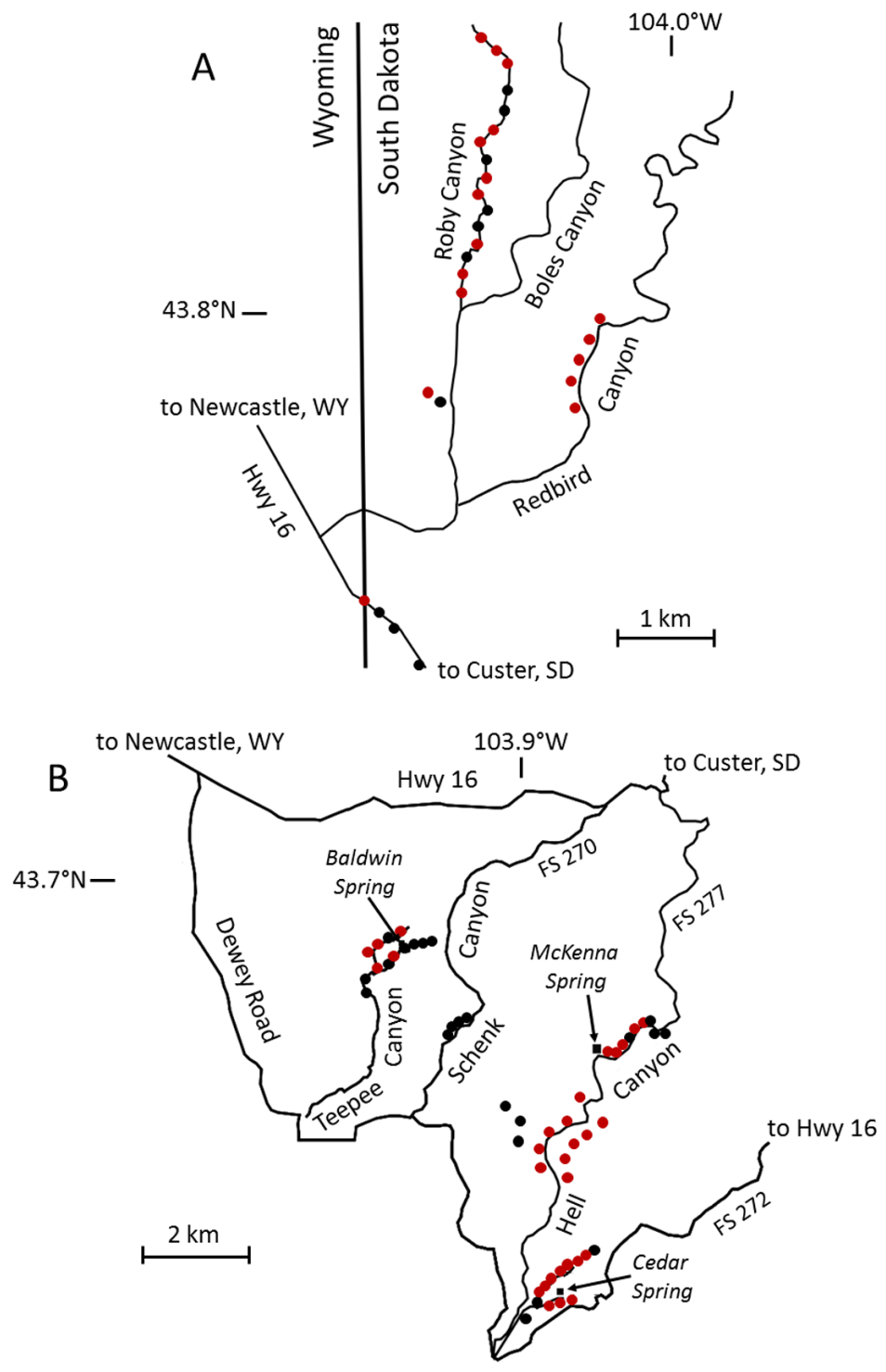

Figure 2. Sites surveyed for Virginia's Warbler in canyons with pine-juniper-shrub habitats in the Black Hills, Custer County, South Dakota. Red dots, Virginia's Warbler detected; black dots, not detected. A, Roby and Redbird canyons; B, Teepee, Schenk and Hell canyons; C, Pleasant Valley Road; D, Beaver and Wind Cave canyons. 

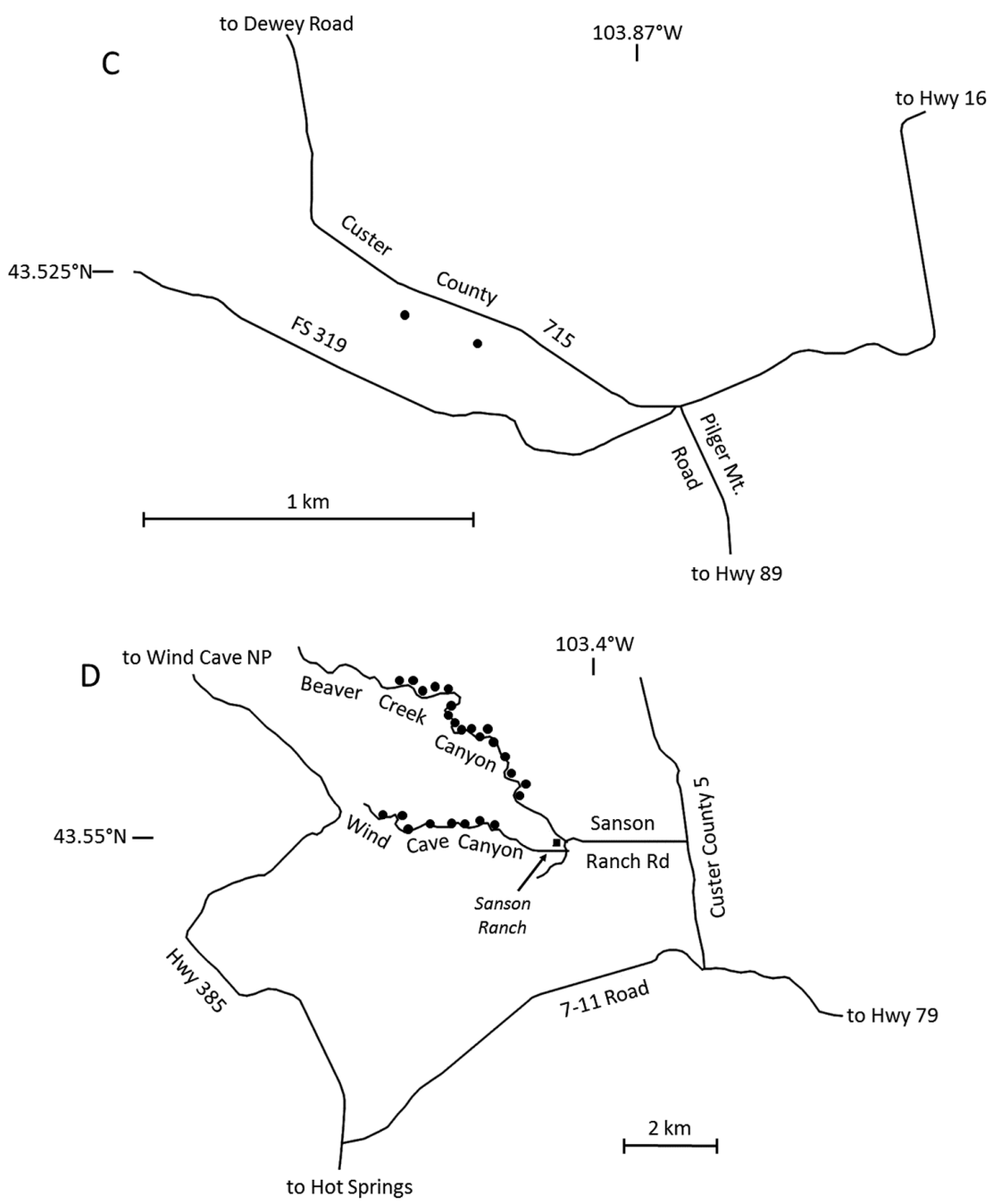

Figure 2 (continued).

Highly ranked logistic regression models for sites in canyons along the southwestern front always included a positive association with shrub cover (Table 2). Most highly ranked models for southwestern front canyons also included negative associations with the Dusky Flycatcher or Spotted Towhee. Co-occurrence of pine overstory and the Yellow-rumped Warbler were included as positive covariates in one highly ranked model each, but $\mathrm{AIC}_{c}$ weights for these models were substantially lower (Table 2). For analyses that included all survey points (including the unoccupied canyons in the Sanson 
Table 2 Logistic Regression Models Evaluating Variables Associated with Occurrence of Virginia's Warbler in the Black Hills

\begin{tabular}{|c|c|c|c|c|}
\hline Model $^{a}$ & $\begin{array}{c}\text { Log } \\
\text { likelihood }\end{array}$ & $K^{b}$ & $\Delta \mathrm{AIC}_{c}$ & $\begin{array}{l}\text { Akaike } \\
\text { weight }\end{array}$ \\
\hline \multicolumn{5}{|c|}{ Models based on 82 sites along the southwestern front of the Black Hills only } \\
\hline shrub (+) SPTO (-) DUFL (-) & 101.815 & 4 & $-^{c}$ & 1.00 \\
\hline shrub (+) DUFL (-) & 104.335 & 3 & 0.31 & 0.86 \\
\hline shrub (+) SPTO (-) & 104.646 & 3 & 0.62 & 0.73 \\
\hline shrub (+) & 107.471 & 2 & 1.29 & 0.52 \\
\hline shrub (+) pine (+) SPTO (-) DUFL (-) & 100.898 & 5 & 1.36 & 0.51 \\
\hline shrub (+) AUWA (+) SPTO (-) DUFL (-) & 101.527 & 5 & 1.99 & 0.37 \\
\hline \multicolumn{5}{|c|}{$\begin{array}{l}\text { Models based on all } 107 \text { sites, along both the southwestern and southeastern fronts } \\
\text { of the Black Hills }\end{array}$} \\
\hline shrub (+) AUWA (+) SPTO (-) & 136.751 & 4 & - & 1.00 \\
\hline shrub (+) pine (+) AUWA (+) SPTO (-) & 134.774 & 5 & 0.23 & 0.89 \\
\hline AUWA (+) SPTO (-) & 139.164 & 3 & 0.26 & 0.88 \\
\hline shrub (+) pine (+) AUWA (+) & 137.318 & 4 & 0.57 & 0.75 \\
\hline +) AUWA (+) SPTO (-) & 137.668 & 4 & 0.92 & 0.63 \\
\hline +) SPTO (-) & 13 & 3 & 1.08 & 0.58 \\
\hline +) SPTO (-) & 138.007 & 4 & 1.26 & 0.53 \\
\hline (+) DUFL (+) AUWA (+) SPTO (-) & 136.055 & 5 & 1.51 & 0.47 \\
\hline SPTO (-) & 142.067 & 2 & 1.04 & 0.59 \\
\hline $\begin{array}{l}\text { shrub (+) AUWA (+) } \\
\text { shrub (+) pine (+) DUFL (+) AUWA (+) }\end{array}$ & 140.123 & 3 & 1.22 & 0.54 \\
\hline SPTO $(-)$ & 134.134 & 6 & 1.83 & 0.40 \\
\hline DUFL (+) AUWA (+) SPTO (-) & 138.174 & 4 & 1.43 & 0.49 \\
\hline DUFL (+) SPTO (-) & 140.273 & 3 & 1.37 & 0.50 \\
\hline pine $(+)$ SPTO (-) & 140.537 & 3 & 1.63 & 0.44 \\
\hline
\end{tabular}

${ }^{a}$ Abbreviations for variables: shrub = category of shrub cover; pine = category of pine overstory; $\mathrm{SPTO}=$ Spotted Towhee co-occurrence DUFL = Dusky Flycatcher co-occurrence; AUWA = Yellow-rumped (Audubon's) Warbler co-occurrence. Plus and minus symbols indicate positive and negative relationships (slopes) of predictor variables with Virginia's Warbler presence.

${ }^{b}$ Number of parameters in the model.

${ }^{c} \mathrm{AIC}_{c}=110.33$

Ranch addition to Wind Cave National Park), co-occurrence of pine overstory and the Yellow-rumped Warbler were included in a number of highly ranked models (Table 2). Shrub cover was also included in most of these models, but a positive association with the Dusky Flycatcher appeared only in models with lower $\mathrm{AIC}_{c}$ weights (Table 2). Slope was excluded as an independent variable in the logistic regression models, as its inclusion led to quasi-separation of points and models that failed to converge, likely because too few sites with slopes $<15^{\circ}$ (none of which had Virginia's Warblers) were sampled.

\section{DISCUSSION}

The Virginia's Warbler population in the Black Hills of South Dakota is the northeasternmost of the species and is over $200 \mathrm{~km}$ from the next nearest regular breeding locations in south-central Wyoming (Swanson et al. 2000). The breeding range of Virginia's Warbler in South Dakota was 
originally reported as including portions of Whoopup Creek, Roby, Boles, Redbird, and Buck Spring canyons north of Highway 16 in Custer County (Figure 1; Swanson et al. 2000). Subsequent surveys (White and Giroir 2009, Bird Conservancy of the Rockies 2015) and additional observations (http://SDOU.org database) also disclosed Virginia's Warblers during the breeding season in Gillette Canyon and at several sites south of Highway 16 in Custer County. The surveys we report here further define the range of Virginia's Warblers in South Dakota, particularly south of Highway 16. This range encompasses PJS habitats along essentially the entire southwestern front of the Black Hills in Custer County, a distance of approximately 30 $\mathrm{km}$. The PJS habitat also extends into Wyoming immediately to the west (Hoffman and Alexander 1987, Gucker 2006, pers. obs.), and Faulkner (2010) reported Virginia's Warbler in it north and east of Newcastle, without specifying its numbers. Although we did not survey PJS habitat in Wyoming, we suspect that Virginia's Warblers also occur for several kilometers west of the state line in numbers similar to those we observed in South Dakota.

We found that percent occurrence and relative abundance of Virginia's Warbler in previously and newly documented portions of the breeding range were similar, suggesting the species' density in PJS habitats throughout its Black Hills distribution is fairly uniform. Swanson et al. (2000) speculated that its relatively high abundance in PJS habitats in the Black Hills suggests that this population is not recently established. The similar percent occurrence and relative abundance at the additional sites we surveyed in 2015 also supports the idea that the habitat is not recently colonized. Our not detecting Virginia's Warblers in Schenk Canyon, where we had found them in multiple previous years, suggests that some sites are occupied in some years but not in others. The PJS habitat in Schenk Canyon covers only approximately 5 hectares, so it probably supports only a few breeding pairs when occupied. Alternatively, by the time of our surveys in early July, nests of the few breeding pairs may have failed and the birds may have abandoned the area. If some suitable sites are occupied in some years but not in others, this might suggest that the PJS habitat in the Black Hills is not fully saturated, which could be considered inconsistent with the idea that the population is long established. The absence of Virginia's Warbler from PJS habitats along the southeastern front of the Black Hills is also consistent with the idea of the species being a recent colonizer that has not fully occupied all available habitats, as suggested by Bubac and Spellman (2016). Further research, including studies of source-sink population dynamics and fine-scale habitat selection, could help resolve the question of whether this population represents a new colonization or has been long established.

Swanson et al. (2000) noted that Virginia's Warblers occur in PJS habitat with relatively dense shrub cover, steep slopes, and medium to large pines, ranging from scattered trees to a relatively complete overstory. Of these habitat variables, steep slopes were significantly positively associated with Virginia's Warbler across all survey points, but not when the analysis was restricted to occupied canyons, and slope (as well as pine cover) could not be included in logistic regression models because of insufficient variability at the points surveyed. Indeed, most of the mahogany-dominated shrub habitats in the southern Black Hills are characterized by slopes ranging from $12^{\circ}$ to 
$21^{\circ}$ and shrub cover ranging from $43 \%$ to $53 \%$, with occasional scattered pines and Rocky Mountain junipers (Juniperus scopulorum) (Hoffman and Alexander 1987). Thus the habitat elements Virginia's Warblers require are common in the PJS habitats of the southern Black Hills. Virginia's Warbler's generally negative association with the Spotted Towhee and positive association with the Yellow-rumped Warbler suggests that Virginia's Warbler prefers at least some scattered pines in its habitat, as the Yellow-rumped is associated with pines, the towhee more closely with open shrubby habitats (Tallman et al. 2002, pers. obs.).

Although the habitat and precipitation along the southeastern front of the Black Hills (Driscoll et al. 2000) are similar to those along the southwestern front, we detected no Virginia's Warblers there. Thus no reason for the species' absence along the southeastern front is obvious, but we observed no Dusky Flycatchers in this areas either, resulting in its occurrence correlating positively with that of Virginia's Warbler when all sites were included in logistic regression models. The lack of these two species along the southeastern front suggests that the PJS habitat along the southwestern and southeastern fronts differ in some important but so far unknown way. Interestingly, in logistic regression models including only canyons along the southwestern front, occurrence of Virginia's Warbler and the Dusky Flycatcher had a weak negative correlation, despite the latter being the third most abundant bird in PJS habitats of that area (Swanson et al. 2000, 2002). This suggests some subtle differences between the two species' preferred habitats in southwestern front canyons, regardless of their positive co-occurrence over all sampled sites.

Because of the isolation of the Black Hills population of Virginia's Warbler, its specific habitat requirements, and the relative scarcity of the PJS habitat in the southern Black Hills (Huking 2008), this population is of conservation concern and is listed by the South Dakota Department of Game, Fish and Parks in its category S3B (species found locally in a restricted range). These characteristics may make the population susceptible to wildfires, which have burned PJS habitats in the Black Hills several times within the past 15 years. The dominant shrub of the PJS habitats, mountain-mahogany, is susceptible to top-killing by fire, but it fairly quickly recolonizes burned areas through sprouts from root crowns or rhizomes (Gucker 2006). Thus a rapid rebound of the shrub layer in PJS habitats after wildfire may also allow Virginia's Warbler to reoccupy these habitats quickly, as long as scattered trees are still available nearby. The species' spread along $>30 \mathrm{~km}$ of the southwestern front of the Black Hills suggests that the population is sufficiently widespread to be able to recolonize burned areas as the PJS habitat recovers.

Breeding Bird Survey data (Sauer et al. 2014) suggest that numbers of Virginia's Warbler are declining range-wide, at an annual rate of $1.3 \%$ from 2003 from 2013. Climate change may further exacerbate this decline. Van Riper et al. (2014) modeled the effects of climate change on birds of the southwestern United States, including Virginia's Warbler; their results suggest a reduction in suitable habitat along with a range-wide population decline of $2 \%$ to $8 \%$ by the year 2099 . The Black Hills population could help buffer this population decline, however, as models predicted an increase in suitable habitat for Virginia's Warbler in the Black Hills (van Riper et al. 2014) over 
this same period. If appropriate habitats within the Black Hills increase, the Virginia's Warbler population there could also increase. Further research detailing specific habitat requirements across a wider range of conditions, at both the local and landscape levels, as well as source-sink population dynamics, would improve prediction of responses to habitat and climate changes for the Black Hills Virginia Warbler population.

\section{ACKNOWLEDGMENTS}

We thank Doug Backlund for giving us a "heads-up" about Virginia's Warblers at Baldwin Springs. We also thank Duane Weber of Wind Cave National Park for alerting us to the presence of PJS habitat in the Sanson addition and for guiding us to this habitat. We also wish to thank Wind Cave National Park for providing permits and permission to survey there. We thank Stephen J. Dinsmore, Chris Olson, and Ron Martin for constructive comments on an earlier version of the manuscript. Funding for the study was provided by a grant (UP1500121) from the Wildlife Diversity Program of the South Dakota Department of Game, Fish and Parks.

\section{LITERATURE CITED}

Bird Conservancy of the Rockies. 2015. The Rocky Mountain Avian Data Center (web application); http://adc.rmbo.org (accessed 15 October 2015).

Bubac, C. M., and Spellman, G. M. 2016. How connectivity shapes genetic structure during range expansion: Insights from the Virginia's Warbler. Auk 133:213-230; doi 10.1642/AUK-15-124.1.

Drilling, N. E., Sparks, R. A., Woiderski, B. J., and Beason, J. P. 2016. South Dakota breeding bird atlas II: Final report. Tech. Rep. M-SDBBA2-07. Rocky Mountain Bird Observatory, Brighton, CO.

Driscoll, D. G., Hamade, G. R., and Kenner, S. J. 2000. Summary of precipitation data for the Black Hills area of South Dakota, water years 1931-98. U.S. Geol. Surv. Open-File Report 00-329.

Faulkner, D. W. 2010. Birds of Wyoming. Roberts and Co., Greenwood Village, CO.

Gucker, C. L. 2006. Cercocarpus montanus, in Fire Effects Information System. U.S. Dept. of Agriculture, Forest Service, Rocky Mountain Research Station, Fire Sciences Laboratory; www.fs.fed.us/database/feis/plants/shrub/cermon/all.html.

Hoffman, G. R., and Alexander, R. R. 1987. Forest vegetation of the Black Hills National Forest of South Dakota and Wyoming: A habitat type classification. U. S. Dept. of Agriculture Forest Service Research Paper RM-276.

Huking, C. (ed.). 2008. FY2007 monitoring and evaluation report. U.S. Dept. of Agriculture, Forest Service, Black Hills National Forest; http://www.fs.usda.gov/ Internet/FSE_DOCUMENTS/stelprdb5112254.pdf.

New Mexico Partners in Flight. 2007. New Mexico bird conservation plan, version 2.1 (C. Rustay and S. Norris, compilers); http://nmpartnersinflight.org/downloads/ BCP\%20Chapters\%201-3.pdf.

Olson, C. R., and Martin, T. E. 1999. Virginia's Warbler (Oreothlypis virginiae), in The Birds of North America (A. Poole and F. Gill, eds.), no 477. Birds N. Am., Philadelphia; doi 10.2173/bna.477.

Palmer, J. S. 1998. First South Dakota record of Virginia's Warbler. South Dakota Bird Notes 50:89-90.

Peterson, R. A. 1996. The South Dakota Breeding Bird Atlas. South Dakota Ornithol. Union, Aberdeen, SD.

Sauer, J. R., Hines, J. E., Fallon, J. E., Pardieck, K. L., Ziolkowski, D. J., Jr., and Link, W. A. 2014. The North American Breeding Bird Survey, results and analysis 
1966-2013, version 01.30.2015. U.S. Geol. Surv. Patuxent Wildlife Research Center, Laurel, MD; http://www.mbr-pwrc.usgs.gov/bbs/bbs.html.

Stephenson, T., and Whittle, S. 2013. The Warbler Guide. Princeton Univ. Press, Princeton, NJ; doi 10.1515/9781400846863.

Swanson, D. L., Palmer, J. S., Liknes, E. T., and Dean, K. L. 2000. A breeding population of Virginia's Warblers in the southwestern Black Hills of South Dakota. Southwestern Naturalist 45:39-44; doi 10.2307/3672550.

Swanson, D. L., Palmer, J. S., Liknes, E. T., and Dean, K. L. 2002. Breeding avifauna of the restricted pine-juniper-shrub habitat in the southwestern Black Hills. South Dakota Bird Notes 54:34-41.

Tallman, D.T., Swanson, D. L., and Palmer, J. S. 2002. Birds of South Dakota, 3rd ed. South Dakota Ornithol. Union, Aberdeen, SD.

Van Riper, C. III, Hatten, J. R., Giermakowski, J. T., Mattson, D., Holmes, J. A., Johnson, M. J., Nowak, E.M., Ironside, K., Peters, M., Heinrich, P., Cole, K. L., Truettner, C., and Schwalbe, C. R. 2014. Projecting climate change effects on birds and reptiles of the southwestern United States. U.S. Geol. Surv., Open-File Report 2014-1050.

White, C., and Giroir, G. 2009. Monitoring the birds of the Black Hills, 2008 field season report. Tech. Rep. M-MBBH-USFS08, SDDGF08. Rocky Mountain Bird Observatory, Brighton, CO.

Accepted 20 April 2016

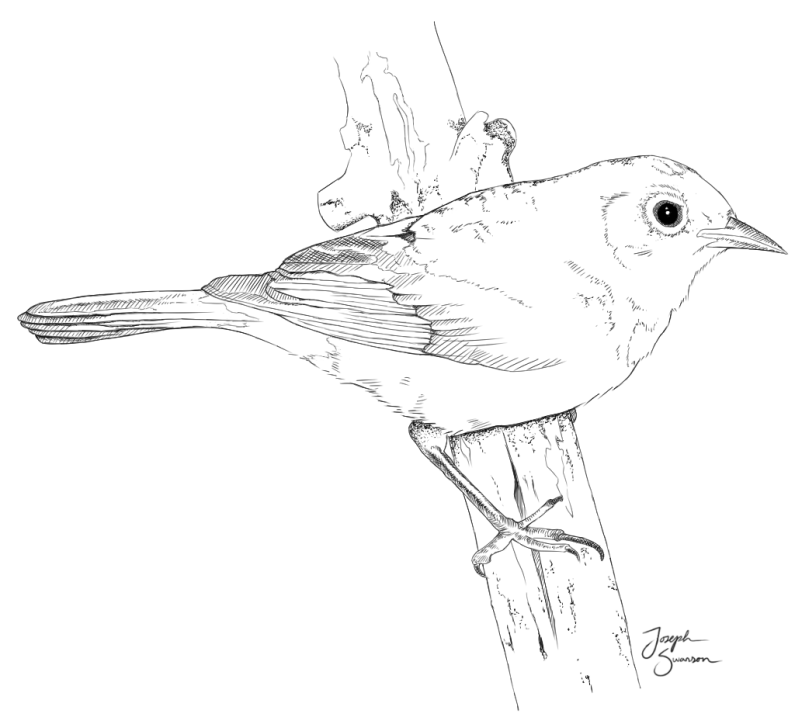

Virginia's Warbler

Sketch by Joseph Swanson 